\title{
Results for the Second Quarter 2013 Tank 50 WAC Slurry Sample
}

Chemical and Radionuclide Contaminants

Christopher J. Bannochie, Ph.D.

July 2013

SRNL-STT-2013-00390 
SRNL-STI-2013-00390

Revision 0

\section{DISCLAIMER}

This work was prepared under an agreement with and funded by the U.S. Government. Neither the U.S. Government or its employees, nor any of its contractors, subcontractors or their employees, makes any express or implied:

1. warranty or assumes any legal liability for the accuracy, completeness, or for the use or results of such use of any information, product, or process disclosed; or

2. representation that such use or results of such use would not infringe privately owned rights; or

3. endorsement or recommendation of any specifically identified commercial product, process, or service.

Any views and opinions of authors expressed in this work do not necessarily state or reflect those of the United States Government, or its contractors, or subcontractors.

Printed in the United States of America

Prepared for

U.S. Department of Energy 
Keywords: Tank 50, Waste Acceptance Criteria, Saltstone

Retention: Permanent

\title{
Results for the Second Quarter 2013 Tank 50 WAC Slurry Sample: Chemical and Radionuclide Contaminants
}

\author{
C. J. Bannochie
}

July 2013 


\section{REVIEWS AND APPROVALS}

\section{AUTHOR:}

C. J. Bannochie, Process Technology Programs

Date

TECHNICAL REVIEW:

M. M. Reigel, Engineering Process Development, Reviewed per E7, 2.60

Date

APPROVAL:

E. N. Hoffman, Manager

Date

Engineering Process Development

S. L. Marra, Manager

Date

Environmental \& Chemical Process Technology Research Programs

J. S. Contardi, Manager

Date

Saltstone Facility Engineering

D. J. Martin, Manager

Date

Tank Farm Flowsheet 


\section{EXECUTIVE SUMMARY}

This report details the chemical and radionuclide contaminant results for the characterization of the 2013 Second Quarter sampling of Tank 50 for the Saltstone Waste Acceptance Criteria (WAC) in effect at that time. ${ }^{1}$ Information from this characterization will be used by Saltstone Facility Engineering (SFE) to support the transfer of low-level aqueous waste from Tank 50 to the Salt Feed Tank in the Saltstone Facility in Z-Area, where the waste will be immobilized. This information is also used to update the Tank 50 Waste Characterization System.

The following conclusions are drawn from the analytical results provided in this report:

- SRR WAC targets or limits were met for all analyzed chemical and radioactive contaminates unless noted in this section.

- ${ }^{59} \mathrm{Ni},{ }^{94} \mathrm{Nb},{ }^{247} \mathrm{Cm},{ }^{249} \mathrm{Cf}$, and ${ }^{251} \mathrm{Cf}$ are above the requested SRR target concentrations ${ }^{2}$. However, they are below the detection limits established by SRNL ${ }^{3}$.

- Norpar 13 and Isopar L have higher detection limits ${ }^{4}$ compared with the Saltstone WAC ${ }^{1}$. The data provided in this report is based upon the concentrations in the sub-sample, and due to the limited solubility in aqueous solution, may not represent the concentrations of the analytes in Tank 50.

- The low insoluble solids content increases the measurement uncertainty for insoluble species. 


\section{TABLE OF CONTENTS}

LIST OF TABLES ...................................................................................................................

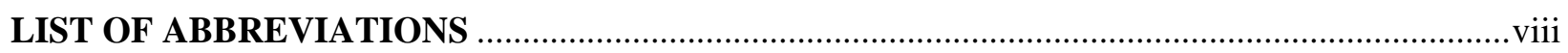

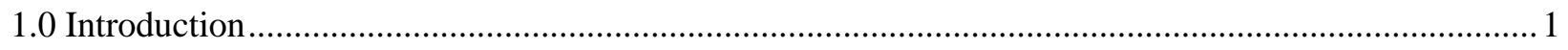

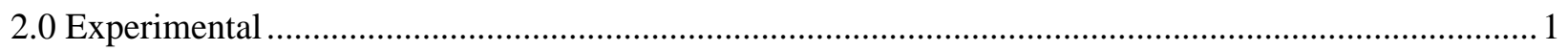

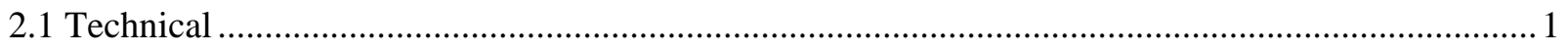

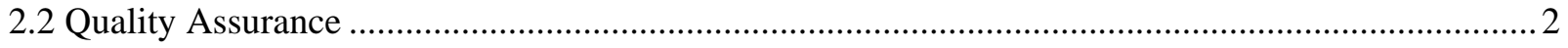

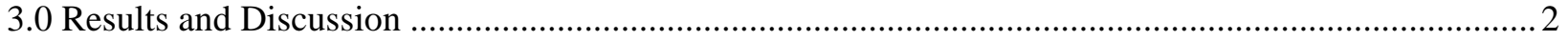

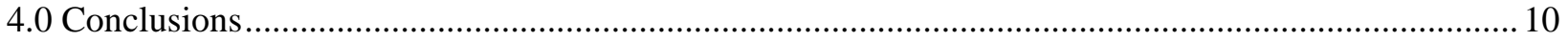

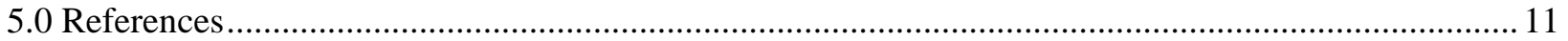


SRNL-STI-2013-00390

Revision 0

\section{LIST OF TABLES}

Table 3-1. Results for the 2nd Quarter 2013 Tank 50 Slurry Samples for Chemical Contaminants Listed in Attachment 8.1 of the Saltstone WAC, Revision 11 ...................................................................... 2

Table 3-2. Results for the 2nd Quarter 2013 Tank 50 Slurry Samples for Chemical Contaminants Listed in

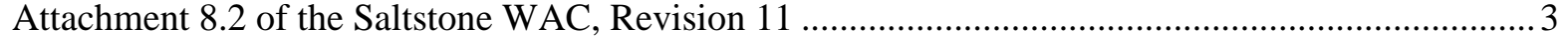

Table 3-3. Results for 2nd Quarter 2013 Tank 50 Slurry Samples and WAC Limits for Radionuclide Contaminants Listed in Attachment 8.3 of the Saltstone WAC, Revision 11 ...................................... 5

Table 3-4. Results for the 2nd Quarter 2013 Tank 50 Slurry Samples and WAC Targets for Radionuclide Contaminants Listed in Attachment 8.4 of the Saltstone WAC, Revision 11 ..................................... 6

Table 3-5. Results for the 2nd Quarter 2013 Tank 50 Slurry Samples for Acceptance Criteria Limits for Chemical Contaminants Impacting Vault Flammability, Listed in Table 3 of the Saltstone WAC, Revision 11 7

Table 3-6. Results for the 2nd Quarter 2013 Tank 50 Slurry Samples for Concentrations of "Other Organics” Impacting Vault Flammability, Listed in Table 4 of the Saltstone WAC, Revision 11 ....... 7

Table 3-7. Results for the 2nd Quarter 2013 Tank 50 Slurry Samples for Saltstone Processing Criteria WAC Limits, Listed in Table 5 of the Saltstone WAC, Revision 11 ................................................. 8

Table 3-8. Requests for Constituents for TCLP/UHC Support as well as from the TTR for the 2nd Quarter 2013 Tank 50 Slurry Samples; Results Not Contained in Previous Tables.............................. 8

Table 3-9. Signal Observed For Masses 203 and 205 - 208 in Digestion Acid and the Tank 50 Sample Blank Showing the Contribution to the Sample Signal Expected from the Digestion Acid

Table 3-10. Requests from the SFE for Corrosion Species from the 2nd Quarter 2013 Tank 50 Slurry Samples; Results Not Contained in Previous Tables........................................................................... 9

Table 3-11. Additional Radionuclides Requested for Inventory Reporting Requirements 10 


\section{LIST OF ABBREVIATIONS}

\begin{tabular}{|c|c|}
\hline AA & Atomic Absorption (spectroscopy) \\
\hline $\mathrm{AD}$ & Analytical Development \\
\hline ARP/MCU & Actinide Removal Process/Modular CSSX Unit \\
\hline CLFL & Composite Lower Flammability Limit \\
\hline CSSX & Caustic Side Solvent Extraction \\
\hline CVAA & Cold Vapor Atomic Absorption \\
\hline DDA & Deliquification, Dissolution and Adjustment \\
\hline EPA & Environmental Protection Agency \\
\hline ETP & Effluent Treatment Project \\
\hline GC/MS & Gas Chromatograph/Mass Spectrometer \\
\hline HDPE & High Density Polyethylene \\
\hline HPLC & High Performance Liquid Chromatography \\
\hline IC & Ion Chromatography \\
\hline ICP-AES & Inductively coupled plasma - atomic emission spectroscopy \\
\hline ICP-MS & Inductively coupled plasma - mass spectrometry \\
\hline L & Liter \\
\hline LLW & Low Level Waste \\
\hline LSC & Liquid Scintillation Counting \\
\hline MDL & Method Detection Limit \\
\hline MRL & Method Reporting Limit \\
\hline mg & Milligram \\
\hline $\mathrm{mL}$ & Milliliter \\
\hline NA & Not Applicable \\
\hline ND & Not Determined \\
\hline $\mathrm{pCi} / \mathrm{mL}$ & Picocurie per milliliter \\
\hline RSD & Relative Standard Deviation \\
\hline SC & Shielded Cells (Facility) \\
\hline SDF & Saltstone Disposal Facility \\
\hline SFE & Saltstone Facility Engineering \\
\hline SFT & Salt Feed Tank \\
\hline SPF & Saltstone Production Facility \\
\hline SRNL & Savannah River National Laboratory \\
\hline SRR & Savannah River Remediation \\
\hline
\end{tabular}




$\begin{array}{ll}\text { SRS } & \text { Savannah River Site } \\ \text { SVOA } & \begin{array}{l}\text { Semi-volatile Organic Analysis } \\ \text { Toxic Characterization Leaching Procedure/Underlying Hazardous }\end{array} \\ \text { TCLP/UHC } & \begin{array}{l}\text { Constituent } \\ \text { Tentatively Identifiable Compound }\end{array} \\ \text { TIC } & \text { Total inorganic carbon/total organic carbon } \\ \text { TIC/TOC } & \text { Task Technical and Quality Assurance Plan } \\ \text { TTQAP } & \text { Technical Task Request } \\ \text { TTR } & \text { Volatile organic analysis } \\ \text { VOA } & \text { Waste Acceptance Criteria } \\ \text { WAC } & \text { Waste Characterization System } \\ \text { WCS } & \text { Weight percent }\end{array}$




\subsection{Introduction}

The Saltstone Facility is designed and permitted to treat low-level radioactive and hazardous liquid waste (salt solution) remaining from the processing of radioactive material at the Savannah River Site. Lowlevel waste (LLW) streams from the Effluent Treatment Project (ETP), H-Canyon, and the decontaminated salt solution product from the Actinide Removal Process/Modular Caustic Side Solvent Extraction (CSSX) Unit (ARP/MCU) process are stored in Tank 50 until the LLW can be transferred to the Saltstone Facility for treatment and disposal. The LLW must meet the specified waste acceptance criteria (WAC) before it is processed into saltstone. ${ }^{1}$ The specific chemical and radionuclide contaminants and their respective WAC limits are in the current ${ }^{\mathrm{a}}$ Saltstone WAC.

Saltstone Facility Engineering (SFE) requested that the Savannah River National Laboratory (SRNL) perform quarterly analysis on saltstone samples. ${ }^{5}$ The concentrations of chemical and radionuclide contaminants are measured to ensure the saltstone produced during each quarter is in compliance with the current WAC. ${ }^{1,5,6}$ This report documents the concentrations of chemical and radionuclide contaminants and discusses those results for the 2013 Second Quarter samples collected from Tank 50 on April 3, 2013.

\subsection{Experimental}

\subsection{Technical}

On April 3, 2013, one 3-L sampler (HTF-50-13-54) and one 200-mL sampler (HTF-50-13-53) were collected from Tank 50 for the Second Quarter 2013 (2Q13) WAC analyses and delivered the same day to the SRNL Shielded Cells (SC). The $200 \mathrm{~mL}$ sampler is a dip sample taken six inches below the surface and the 3-L sampler was pulled 66 inches from the bottom of the tank with one agitator pump running.

At SRNL, slurry samples ( 15 mL each) from HTF-50-13-53 were transferred with glass pipettes to glass vials with Teflon-lined caps. The vials were completely filled to minimize the void space and the volatilization of organics. The aliquots were transferred to the Analytical Development (AD) Organic Analysis Laboratory for semi-volatile and volatile organic analysis (SVOA and VOA, respectively). Two additional 15-mL aliquots were used for SVOA analysis to determine the concentration of Isopar L and Norpar 13, respectively, in the sample.

After the samples for organic analyses were obtained, the slurries in the steel samplers were combined into a 4-L high-density polyethylene (HDPE) bottle. The $200 \mathrm{~mL}$ steel sampler was agitated to disperse any solids in the slurry and poured into the 4-L bottle. The transferred slurry was left to settle in the 4- $\mathrm{L}$ bottle. Visual inspection of the inside of each sampler indicated there were no visible solids remaining in the samplers, so no clear supernate was returned to either sampler for rinsing. The total weight of the transferred slurry was $4040.39 \mathrm{~g}$.

The 4-L HDPE bottle was agitated to disperse thoroughly the extremely limited solids into the supernate. Aliquots of slurry samples were promptly collected with slurry pipettes to minimize settling effects and placed into HDPE bottles. A three-milliliter sample of the slurry was used to determine the density of the slurry using an Anton-Paar DMA 35n portable density meter.

Slurry samples were submitted in triplicate to SRNL laboratories for the following analyses:

\footnotetext{
a This report references the Saltstone WAC revision in effect when the sample is pulled for analysis and/or that which was referenced during initial data reporting. This may or may not be the latest revision when this report receives its final approval signature.
} 
- Six-mL aliquots to the AD Ion Chromatography (IC) Laboratory for soluble anion and cation analyses.

- Three-mL aliquots to the AD Organic Analysis Laboratory for measurement of tetraphenylborate and ethylenediaminetetraacetate by high performance liquid chromatography (HPLC).

- Six-mL aliquots to the AD Wet Chemistry Laboratory for Total Inorganic Carbon/ Total Organic Carbon (TIC/TOC) analyses.

- Two 70-mL aliquots to AD Radiochemistry Laboratory for radiochemical separations and analyses.

- Twelve-mL aliquots of filtered supernate were prepared by filtering aliquots of supernate using a 0.45 micron syringe filter. The filtered supernate samples were then submitted to the AD Wet Chemistry Laboratory for TIC/TOC analyses and Total Base analyses.

- Two 12-mL aliquots were sent to the AD Dissolution Laboratory for digestion using an aqua regia method ${ }^{7}$. Visual inspection of the digested sample by the AD Task Supervisor indicated that all the solids had dissolved. Aliquots of dissolved slurries were analyzed using inductively coupled plasma - atomic emission spectroscopy (ICP-AES), inductively coupled plasma mass spectrometry (ICP-MS), atomic absorption spectroscopy (AA) for As, K, Na, and Se, and cold vapor atomic absorption spectroscopy (CVAA) for Hg.

Four additional aliquots of supernate were prepared from the combined slurry sample since there was no original surface sample remaining to sample. These samples were submitted for replicate SVOA analyses using two different extraction solvents: the traditional methylene chloride extraction and an additional hexane extraction.

\subsection{Quality Assurance}

Requirements for performing reviews of technical reports and the extent of review are established in manual E7 2.60. SRNL documents the extent and type of review using the SRNL Technical Report Design Checklist contained in WSRC-IM-2002-00011, Rev. 2.

\subsection{Results and Discussion}

The following tables contain the results for the 2Q13 WAC analyses. Each table provides the analyte of interest, the method used for measuring that analyte, the average concentration of the analyte based on triplicate samples (unless otherwise noted), the standard deviation of the average, and, if applicable, the WAC target or limit for the analyte concentration. Several of the contaminants were either not detected in the slurry samples or detected at values below the method-reporting limit (MRL). For those analytes, the result is preceded by a "<" which indicates the result is an upper limit based on the sensitivity of the method/equipment used to analyze the individual analyte.

Tables 3-1, 3-2, 3-3 and 3-4 are based directly on attachments 8.1, 8.2, 8.3, and 8.4, respectively, of the WAC. ${ }^{1}$

Table 3-1. Results for the 2nd Quarter 2013 Tank 50 Slurry Samples for Chemical Contaminants Listed in Attachment 8.1 of the Saltstone WAC, Revision 11

\begin{tabular}{|l|c|c|c|c|}
\hline Chemical Name & $\underline{\text { Method }}$ & $\frac{\text { Average Concentration }}{\mathbf{( m g / L )}}$ & $\underline{\text { Std. Dev. }}$ & $\frac{\text { WAC Limit }}{\mathbf{( m g / L )}}$ \\
\hline Ammonium $\left(\mathrm{NH}_{4}{ }^{+}\right)$ & IC & $<1.00 \mathrm{E}+02$ & NA & $\mathbf{5 . 8 8 E + 0 3}$ \\
\hline Carbonate $\left(\mathrm{CO}_{3}{ }^{2-}\right)$ & TIC & $1.27 \mathrm{E}+04^{\mathrm{a}}$ & $5.00 \mathrm{E}+01$ & $\mathbf{1 . 2 0 E + 0 5}$ \\
\hline
\end{tabular}




\begin{tabular}{|c|c|c|c|c|}
\hline Chemical Name & $\underline{\text { Method }}$ & $\frac{\text { Average Concentration }}{(\mathrm{mg} / \mathrm{L})}$ & $\underline{\text { Std. Dev. }}$ & $\frac{\text { WAC Limit }}{(\mathrm{mg} / \mathrm{L})}$ \\
\hline Chloride ( $\left.\mathrm{Cl}^{-}\right)$ & IC & $<5.00 \mathrm{E}+02$ & NA & $7.95 \mathrm{E}+03$ \\
\hline Fluoride (F) & IC & $<5.00 \mathrm{E}+02$ & NA & $4.07 E+03$ \\
\hline Free Hydroxide ( $\left.\mathrm{OH}^{-}\right)$ & Total base & $3.12 \mathrm{E}+04^{\mathrm{a}}$ & $2.05 E+03$ & $1.58 \mathrm{E}+05$ \\
\hline Nitrate $\left(\mathrm{NO}_{3}{ }^{-}\right)$ & IC & $1.30 \mathrm{E}+05$ & $1.15 \mathrm{E}+03$ & $4.37 \mathrm{E}+05$ \\
\hline Nitrite $\left(\mathrm{NO}_{2}^{-}\right)$ & IC & $2.01 \mathrm{E}+04$ & $1.01 \mathrm{E}+02$ & $2.14 \mathrm{E}+05$ \\
\hline Oxalate $\left(\mathrm{C}_{2} \mathrm{O}_{4}{ }^{2-}\right)$ & IC & $5.18 \mathrm{E}+02$ & $2.31 \mathrm{E}+00$ & $2.72 E+04$ \\
\hline Phosphate $\left(\mathrm{PO}_{4}{ }^{3-}\right)$ & ICP-ES & $4.79 \mathrm{E}+02$ & $1.91 \mathrm{E}+01$ & $2.94 E+04$ \\
\hline Sulfate $\left(\mathrm{SO}_{4}{ }^{2-}\right)$ & IC & $4.68 \mathrm{E}+03$ & $1.41 \mathrm{E}+02$ & $5.69 \mathrm{E}+04$ \\
\hline Arsenic (As) & AA & $<9.54 \mathrm{E}-02$ & NA & $1.50 \mathrm{E}+02$ \\
\hline Barium (Ba) & ICP-ES & $<4.60 \mathrm{E}-01$ & NA & $6.19 \mathrm{E}+02$ \\
\hline Cadmium (Cd) & ICP-ES & $<7.02 \mathrm{E}-01$ & NA & $3.10 \mathrm{E}+02$ \\
\hline Chromium (Cr) & ICP-ES & $3.66 \mathrm{E}+01$ & 5.14E-01 & $1.24 E+03$ \\
\hline Lead $(\mathrm{Pb})$ & ICP-MS & $1.40 \mathrm{E}-00^{\mathrm{e}}$ & 1.45E-01 & $6.19 \mathrm{E}+02$ \\
\hline Mercury (Hg) & CVAA & $6.06 \mathrm{E}+01$ & $1.08 \mathrm{E}+00$ & $3.25 \mathrm{E}+02$ \\
\hline Selenium (Se) & AA & $<1.90 \mathrm{E}-01$ & NA & $4.46 \mathrm{E}+02$ \\
\hline Silver (Ag) & ICP-ES & $<9.71 \mathrm{E}-01$ & NA & $6.19 E+02$ \\
\hline Aluminum (Al) & ICP-ES & $4.12 \mathrm{E}+03$ & $3.11 \mathrm{E}+01$ & $1.16 \mathrm{E}+05$ \\
\hline Potassium (K) & AA & $2.45 \mathrm{E}+02$ & $3.71 \mathrm{E}+00$ & $3.03 E+04$ \\
\hline Nickel Hydroxide & ICP-ES & $<1.48 \mathrm{E}+01^{\mathrm{d}}$ & NA & 1.17E+03 \\
\hline n-Butanol & VOA & $<5.00 \mathrm{E}-01^{\mathrm{b}}$ & NA & $7.73 E+00$ \\
\hline i-Butanol & VOA & $<5.00 \mathrm{E}-01^{\mathrm{b}}$ & NA & $7.73 E+00$ \\
\hline i-Propanol & VOA & $<2.50 \mathrm{E}-01^{\mathrm{b}}$ & NA & $1.88 \mathrm{E}+00$ \\
\hline Phenol & SVOA & $<1.00 \mathrm{E}+01^{\mathrm{b}}$ & NA & $7.50 \mathrm{E}+02$ \\
\hline Isopar L & SVOA & $<2.67 \mathrm{E}+01 \mathrm{ppm}^{\mathrm{b}, \mathrm{c}}$ & NA & $6.56 \mathrm{E}+01 \mathrm{ppm}$ \\
\hline Total organic carbon & TOC & $3.74 \mathrm{E}+02^{\mathrm{a}}$ & $2.03 \mathrm{E}+01$ & $5.00 \mathrm{E}+03$ \\
\hline $\begin{array}{l}\text { Tetraphenylborate } \\
\text { (TPB anion) }\end{array}$ & HPLC & $<5.00 \mathrm{E}+00$ & NA & $5.00 \mathrm{E}+00$ \\
\hline
\end{tabular}

a. Measurement performed on filtered supernate samples.

b. Measurement performed on duplicate samples rather than triplicate samples.

c. Result is calculated from the reported concentration of $<33 \mathrm{mg} / \mathrm{L}$ and the density of the slurry sample listed in Table 3-8.

d. Result is calculated from the measured Ni concentration assuming all of the Ni is present as the hydroxide compound.

e. Blank value was of comparable magnitude indicating that there may be little to no $\mathrm{Pb}$ in the sample.

Table 3-2. Results for the 2nd Quarter 2013 Tank 50 Slurry Samples for Chemical Contaminants Listed in Attachment 8.2 of the Saltstone WAC, Revision 11

\begin{tabular}{|l|c|c|c|c|}
\hline Chemical Name & $\underline{\text { Method }}$ & $\underline{\text { Average Concentration (mg/L) }}$ & $\underline{\text { Std. Dev. }}$ & $\underline{\underline{\text { WAC TARGET }}}$ \\
\hline Boron (B) & ICP-ES & $5.10 \mathrm{E}+01$ & $7.55 \mathrm{E}-01$ & $\mathbf{7 . 4 3 E + \mathbf { L 2 }}$ \\
\hline Cobalt (Co) & ICP-MS & $<3.87 \mathrm{E}-02$ & NA & $\mathbf{7 . 4 3 E + 0 2}$ \\
\hline Copper (Cu) & ICP-ES & $8.85 \mathrm{E}-01^{\mathrm{C}}$ & NA & $\mathbf{7 . 4 3 E + 0 2}$ \\
\hline Iron (Fe) & ICP-ES & $6.39 \mathrm{E}+00$ & $2.17 \mathrm{E}-01$ & $\mathbf{4 . 9 5 E + 0 3}$ \\
\hline Lithium (Li) & ICP-ES & $1.18 \mathrm{E}+01$ & $1.03 \mathrm{E}-01$ & $\mathbf{7 . 4 3 E + 0 2}$ \\
\hline Manganese (Mn) & ICP-ES & $2.59 \mathrm{E}+00$ & $1.43 \mathrm{E}-02$ & $\mathbf{7 . 4 3 E + 0 2}$ \\
\hline Molybdenum (Mo) & ICP-ES & $<8.52 \mathrm{E}+00$ & NA & $\mathbf{7 . 4 3 E + 0 2}$ \\
\hline Nickel (Ni) & ICP-ES & $<9.40 \mathrm{E}+00$ & NA & $\mathbf{7 . 4 3 E + 0 2}$ \\
\hline
\end{tabular}


SRNL-STI-2013-00390

Revision 0

\begin{tabular}{|l|c|c|c|c|}
\hline Chemical Name & $\underline{\text { Method }}$ & $\underline{\text { Average Concentration }(\mathbf{m g} / \mathbf{L})}$ & $\underline{\text { Std. Dev. }}$ & $\frac{\text { WAC TARGET }}{\mathbf{( m g / L )}}$ \\
\hline Silicon (Si) & ICP-ES & $3.38 \mathrm{E}+01$ & $3.53 \mathrm{E}+00$ & $\mathbf{1 . 0 7 E}+\mathbf{0 4}$ \\
\hline Strontium (Sr) & ICP-ES & $<4.34 \mathrm{E}-02$ & NA & $\mathbf{7 . 4 3 E + 0 2}$ \\
\hline Zinc (Zn) & ICP-ES & $6.89 \mathrm{E}+00$ & $2.00 \mathrm{E}-01$ & $\mathbf{8 . 0 3 E + 0 2}$ \\
\hline Benzene & VOA & $<1.50 \mathrm{E}-01^{\mathrm{a}}$ & NA & $\mathbf{3 . 1 0 E}+\mathbf{0 2}$ \\
\hline Methanol & VOA & b & NA & $\mathbf{1 . 8 8 E + 0 0}$ \\
\hline Toluene & VOA & $<1.50 \mathrm{E}-01^{\mathrm{a}}$ & NA & $\mathbf{3 . 1 0 E}+\mathbf{0 2}$ \\
\hline Dibutylphosphate (DBP) & IC & $<2.75 \mathrm{E}+02$ & NA & $\mathbf{3 . 4 7 E + 0 2}$ \\
\hline Tributyl Phosphate (TBP) & SVOA & $<7.50 \mathrm{E}-01^{\mathrm{a}}$ & NA & $\mathbf{7 . 5 0 E}+\mathbf{0 0}$ \\
\hline EDTA & HPLC & $<1.00 \mathrm{E}+02$ & NA & $\mathbf{3 . 1 0 E}+\mathbf{0 2}$ \\
\hline Norpar 13 & SVOA & $<7.50 \mathrm{E}-01^{\mathrm{a}}$ & NA & $\mathbf{1 . 0 0 E - 0 1}$ \\
\hline
\end{tabular}

a. Measurement performed on duplicate samples rather than triplicate samples.

b. Currently, a routine method for detecting this species does not exist in SRNL.

c. Measurement based on a single sample with a value above the detection limit.

As indicated in Tables 3-1 and 3-2, all of the contaminants are within the WAC limits with the exception of Norpar 13. In October 2010, SRNL reviewed the MRL's for the organic constituents in Tank 50. All of the MRL's are at or below the WAC limits for the organics with the exception of Norpar 13, which has an MRL of $0.75 \mathrm{mg} / \mathrm{L}$, which is above the WAC limit. ${ }^{5}$ Isopar L, and Norpar 13 have negligible solubility in aqueous solutions, which makes it difficult to obtain reliable sub-samples of the original sample. The values reported in these tables are the concentrations as detected by the GC/MS but may not necessarily be an accurate representation of the concentrations of these analytes in Tank 50.

Along with phenol and TBP, the initial SVOA analyses of the surface dip sample indicated the presence of chloromethylmercury or methylmercury chloride $\left(\mathrm{CH}_{3} \mathrm{HgCl}\right)$. This was unexpected because no diphenylmercury was observed in the VOA analyses. In order to determine if the chloromethylmercury observed was a product formed in the GC-MS injection port from reaction of the methylene chloride extractant and the high soluble mercury content of this quarter's sample, another set of samples needed to be tested. There was no remaining surface sample to extract, since it had been combined with the larger 3-L depth sample after the initial organic analysis samples were prepared; therefore, supernate was collected from the full sample and the SVOA extraction was repeated twice using methylene chloride, and twice using hexane as the extractant. When analyzed by GC-MS, the samples extracted with the methylene chloride again indicated the presence of chloromethylmercury, while the hexane extractions showed no measureable chloromethylmercury. We concluded that the chloromethylmercury was a reaction product formed in the $250^{\circ} \mathrm{C}$ GC-MS injection port from methylene chloride and extracted $\mathrm{Hg}$, and that it was not a material that was present in the 2Q13 Tank 50 WAC sample. No specific references to this reaction were located in the literature, but the formation of mixed alkylmercury chloride species have been shown to form in a GC-MS during analysis of a mixture of methyl mercury chloride and diphenylmercury, yielding methylphenylmercury which was not in the starting sample ${ }^{8}$. 
Table 3-3. Results for 2nd Quarter 2013 Tank 50 Slurry Samples and WAC Limits for Radionuclide Contaminants Listed in Attachment 8.3 of the Saltstone WAC, Revision 11

\begin{tabular}{|c|c|c|c|c|}
\hline$\underline{\text { Radionuclide }}$ & Method & $\frac{\begin{array}{c}\text { Average } \\
\text { Concentration }\end{array}}{\text { (pCi/mL) }}$ & $\underline{\text { Std. Dev. }}$ & $\frac{\text { WAC LIMIT }}{(\mathbf{p C i} / \mathrm{mL})}$ \\
\hline Tritium $\left({ }^{3} \mathbf{H}\right)$ & Tritium counting & $5.03 \mathrm{E}+02$ & $4.23 \mathrm{E}+01$ & $5.63 E+05$ \\
\hline Carbon-14 $\left({ }^{14} \mathrm{C}\right)$ & C-14 Liquid scintillation & $4.80 \mathrm{E}+02$ & $6.13 \mathrm{E}+01$ & $1.13 E+05$ \\
\hline Nickel-63 $\left({ }^{63} \mathrm{Ni}\right)$ & $\mathrm{Ni}-59 / 63$ & $<1.32 \mathrm{E}+01$ & NA & $1.13 E+05$ \\
\hline Strontium-90 ( $\left.{ }^{90} \mathrm{Sr}\right)$ & Sr-90 Liquid scintillation & $4.54 \mathrm{E}+03$ & $3.64 \mathrm{E}+02$ & $2.25 E+07$ \\
\hline Technetium-99 $\left({ }^{99} \mathrm{Tc}\right)$ & Tc-99 Liquid scintillation & $2.13 \mathrm{E}+04$ & $1.18 \mathrm{E}+03$ & $2.11 \mathrm{E}+05$ \\
\hline Iodine-129 $\left({ }^{129} \mathrm{I}\right)$ & $\begin{array}{l}\text { I-129 (w/ separation) } \\
\text { Liquid scintillation }\end{array}$ & $1.26 \mathrm{E}+01$ & $1.10 \mathrm{E}+00$ & $3.80 \mathrm{E}+02$ \\
\hline Cesium-137 ( $\left.{ }^{137} \mathrm{Cs}\right)$ & Gamma Scan & $1.07 \mathrm{E}+06$ & $1.19 \mathrm{E}+04$ & $7.13 E+06$ \\
\hline Uranium-233 $\left({ }^{233} U\right)$ & ICP-MS & $<1.67 \mathrm{E}+02$ & NA & $1.13 E+04$ \\
\hline Uranium-235 $\left({ }^{235} \mathrm{U}\right)$ & ICP-MS & $1.66 \mathrm{E}-01$ & $1.47 \mathrm{E}-02$ & $1.13 E+02$ \\
\hline Plutonium-241 ( $\left.{ }^{241} \mathrm{Pu}\right)$ & $\begin{array}{l}\text { Pu238/241 Liquid } \\
\text { scintillation }\end{array}$ & $<3.82 \mathrm{E}+02$ & NA & $8.38 E+05$ \\
\hline Total Alpha & Liquid Scintillation Counting & $<4.82 \mathrm{E}+03$ & NA & $2.50 \mathrm{E}+05$ \\
\hline
\end{tabular}

As shown in Table 3-4, none of the radionuclide contaminants exceeds the targets listed in the latest revision of the WAC. In a memo from Savannah River Remediation (SRR), the requested detection limits for several radionuclides were lowered in order to accommodate future inventory reporting requirements. $^{2}$ The reported detection limits of ${ }^{59} \mathrm{Ni}$ and ${ }^{94} \mathrm{Nb}$ are above the limits requested by SRR $(6.59 \mathrm{E}+00 \text { and } 2.00 \mathrm{E}-03 \mathrm{pCi} / \mathrm{mL} \text {, respectively })^{2}$ but below the quantification limits established by SRNL $\left(2.00 \mathrm{E}+01\right.$ and $4.38 \mathrm{E}-01 \mathrm{pCi} / \mathrm{mL}$, respectively). ${ }^{3}$

The concentration of ${ }^{135} \mathrm{Cs}$ is calculated by assigning all of the mass at 135 to cesium. It is assumed all the mass detected at mass 244 is ${ }^{244} \mathrm{Pu}$. The Pu alpha Pulse Height Analysis (PHA) method does not resolve the alpha activities of ${ }^{239} \mathrm{Pu}$ and ${ }^{240} \mathrm{Pu}$. To determine the maximum concentration of each radionuclide, the total activity is assigned to each radionuclide separately. As shown in Table 3-4, the reported activity is below the WAC target for each radionuclide. 
Table 3-4. Results for the 2nd Quarter 2013 Tank 50 Slurry Samples and WAC Targets for Radionuclide Contaminants Listed in Attachment 8.4 of the Saltstone WAC, Revision 11

\begin{tabular}{|c|c|c|c|c|}
\hline$\underline{\text { Radionuclide }}$ & Method & $\frac{\text { Average Concentration }}{(\mathbf{p C i} / \mathrm{mL})}$ & Std. Dev. & $\frac{\text { WAC TARGET }}{\text { (pCi/mL) }}$ \\
\hline Aluminum-26 $\left({ }^{26} \mathrm{Al}\right)$ & $\begin{array}{l}\text { Gamma scan } \\
\text { (Cs removed) }\end{array}$ & $<1.69 \mathrm{E}-01$ & NA & $2.88 E+03$ \\
\hline Cobalt-60 $\left({ }^{60} \mathrm{Co}\right)$ & $\begin{array}{l}\text { Gamma scan } \\
\text { (Cs removed) }\end{array}$ & 3.37E-01 & 2.89E-02 & $4.87 E+03$ \\
\hline Potassium-40 $\left({ }^{40} \mathrm{~K}\right)$ & $\begin{array}{l}\text { Gamma scan } \\
\text { (Cs removed) }\end{array}$ & $<1.90 \mathrm{E}+00$ & NA & $1.00 \mathrm{E}+02$ \\
\hline Nickel-59 ( $\left.{ }^{59} \mathrm{Ni}\right)$ & $\mathrm{Ni}-59 / 63$ & $<1.35 \mathrm{E}+01$ & NA & $1.13 E+03$ \\
\hline Selenium-79 $\left({ }^{79} \mathrm{Se}\right)$ & Se-79 & $1.77 \mathrm{E}+01$ & $4.70 \mathrm{E}+00$ & $1.90 \mathrm{E}+04$ \\
\hline Zirconium-93 $\left({ }^{93} \mathrm{Zr}\right)$ & $\begin{array}{c}\text { Zr-93 Liquid } \\
\text { scintillation }\end{array}$ & $<4.14 \mathrm{E}+01$ & NA & $1.00 \mathrm{E}+05$ \\
\hline Niobium-94 $\left({ }^{94} \mathrm{Nb}\right)$ & $\begin{array}{l}\text { Gamma scan } \\
\text { (Cs removed) }\end{array}$ & $<3.69 \mathrm{E}-01$ & NA & $1.53 E+02$ \\
\hline Ruthenium-106 $\left({ }^{106} \mathrm{Ru}\right)$ & $\begin{array}{l}\text { Gamma scan } \\
\text { (Cs removed) }\end{array}$ & $<2.38 \mathrm{E}+00$ & NA & $1.13 E+06$ \\
\hline Antimony-125 $\left({ }^{125} \mathrm{Sb}\right)$ & $\begin{array}{l}\text { Gamma scan } \\
\text { (Cs removed) }\end{array}$ & $4.26 \mathrm{E}+01$ & $1.48 \mathrm{E}+00$ & $3.99 E+04$ \\
\hline Tin-126 ( $\left.{ }^{126} \mathrm{Sn}\right)$ & $\begin{array}{l}\text { Gamma scan } \\
\text { (Cs removed) }\end{array}$ & $1.29 \mathrm{E}+02$ & $2.15 \mathrm{E}+01$ & $1.80 \mathrm{E}+04$ \\
\hline Cesium-134 $\left({ }^{134} \mathrm{Cs}\right)$ & Gamma Scan & $<3.12 \mathrm{E}+01$ & NA & $3.28 \mathrm{E}+04$ \\
\hline Cesium-135 ( $\left({ }^{135} \mathrm{Cs}\right)$ & ICP-MS & $<1.99 \mathrm{E}+01$ & NA & $1.50 \mathrm{E}+03$ \\
\hline Cerium-144 ( $\left({ }^{144} \mathrm{Ce}\right)$ & $\begin{array}{l}\text { Gamma scan } \\
\text { (Cs removed) }\end{array}$ & $<2.45 \mathrm{E}+00$ & NA & 1.13E+05 \\
\hline Promethium-147 ( $\left.{ }^{147} \mathrm{Pm}\right)$ & $\begin{array}{l}\text { Pm-147/Sm-151 } \\
\text { Liquid } \\
\text { scintillation }\end{array}$ & $<4.86 \mathrm{E}+01$ & NA & $5.63 E+06$ \\
\hline Samarium-151 ( $\left.{ }^{151} \mathrm{Sm}\right)$ & $\begin{array}{c}\text { Pm-147/Sm-151 } \\
\text { Liquid } \\
\text { scintillation }\end{array}$ & $<3.19 \mathrm{E}+01$ & NA & $2.25 E+04$ \\
\hline Europium-154 $\left({ }^{154} \mathrm{Eu}\right)$ & $\begin{array}{l}\text { Gamma scan } \\
\text { (Cs removed) }\end{array}$ & $2.84 \mathrm{E}+00$ & $1.66 \mathrm{E}-01$ & 8.03E+03 \\
\hline Europium-155 $\left({ }^{155} \mathbf{E u}\right)$ & $\begin{array}{l}\text { Gamma scan } \\
\text { (Cs removed) }\end{array}$ & $<1.22 \mathrm{E}+00$ & NA & $1.13 E+04$ \\
\hline Radium-226 $\left({ }^{226} \mathrm{Ra}\right)$ & Ra-226 & $<8.76 \mathrm{E}+00$ & NA & $1.00 \mathrm{E}+03$ \\
\hline Radium-228 $\left({ }^{228} \mathrm{Ra}\right)$ & $\begin{array}{l}\text { Gamma scan } \\
\text { (Cs removed) }\end{array}$ & $<1.41 \mathrm{E}+00$ & NA & $1.00 \mathrm{E}+04$ \\
\hline Actinium-227 $\left({ }^{227} \mathrm{Ac}\right)$ & Th-229/230 & $<2.10 \mathrm{E}-02$ & NA & $1.00 \mathrm{E}+04$ \\
\hline Thorium-229 ( $\left.{ }^{229} \mathrm{Th}\right)$ & Th-229/230 & $<3.25 \mathrm{E}-02$ & NA & $1.63 E+05$ \\
\hline Thorium-230 $\left({ }^{230} \mathrm{Th}\right)$ & Th-229/230 & $<2.02 \mathrm{E}-02$ & NA & $6.26 \mathrm{E}+03$ \\
\hline Thorium-232 ( $\left.{ }^{232} \mathrm{Th}\right)$ & ICP-MS & $<1.90 \mathrm{E}-03$ & NA & $2.88 E+03$ \\
\hline Protactinium-231 $\left({ }^{231} \mathrm{~Pa}\right)$ & Pa-231 & $<1.04 \mathrm{E}+00$ & NA & $1.00 \mathrm{E}+03$ \\
\hline Uranium-232 $\left({ }^{232} \mathrm{U}\right)$ & U-232 & $2.59 \mathrm{E}+00$ & $1.23 \mathrm{E}+00$ & $1.71 \mathrm{E}+05$ \\
\hline Uranium-234 $\left({ }^{234} \mathrm{U}\right)$ & ICP-MS & $<1.08 \mathrm{E}+02$ & NA & 1.13E+04 \\
\hline Uranium-236 $\left({ }^{236} \mathrm{U}\right)$ & ICP-MS & $<1.12 \mathrm{E}+00$ & NA & 1.13E+04 \\
\hline Uranium-238 $\left({ }^{238} \mathrm{U}\right)$ & ICP-MS & $3.90 \mathrm{E}+00$ & 9.36E-02 & $1.13 E+04$ \\
\hline Neptunium-237 $\left({ }^{237} \mathrm{~Np}\right)$ & ICP-MS & $<1.22 \mathrm{E}+01$ & NA & $1.00 \mathrm{E}+04$ \\
\hline
\end{tabular}


SRNL-STI-2013-00390

Revision 0

\begin{tabular}{|c|c|c|c|c|}
\hline$\underline{\text { Radionuclide }}$ & Method & $\frac{\text { Average Concentration }}{\text { (pCi//mL) }}$ & $\underline{\text { Std. Dev. }}$ & $\frac{\text { WAC TARGET }}{\underline{(\mathrm{pCi} / \mathrm{mL})}}$ \\
\hline Plutonium-238 $\left({ }^{238} \mathrm{Pu}\right)$ & $\begin{array}{c}\text { Pu238/241 } \\
\text { Pu alpha PHA }\end{array}$ & $1.18 \mathrm{E}+03$ & $7.32 \mathrm{E}+01$ & $2.50 \mathrm{E}+05$ \\
\hline Plutonium-239 $\left({ }^{239} \mathbf{P u}\right)$ & $\begin{array}{c}\text { Pu238/241 } \\
\text { Pu alpha PHA }\end{array}$ & $1.20 \mathrm{E}+02$ & $6.92 \mathrm{E}+00$ & $2.50 \mathrm{E}+05$ \\
\hline Plutonium-240 $\left({ }^{240} \mathrm{Pu}\right)$ & $\begin{array}{c}\text { Pu238/241 } \\
\text { Pu alpha PHA }\end{array}$ & $1.20 \mathrm{E}+02$ & $6.92 \mathrm{E}+00$ & $2.50 \mathrm{E}+05$ \\
\hline Plutonium-242 ( $\left.{ }^{242} \mathrm{Pu}\right)$ & ICP-MS & $<6.60 \mathrm{E}+01$ & NA & $2.50 \mathrm{E}+05$ \\
\hline Plutonium-244 $\left({ }^{244} \mathrm{Pu}\right)$ & ICP-MS & $<3.07 \mathrm{E}-01$ & NA & $7.02 E+04$ \\
\hline Americium-241 ( $\left.{ }^{241} \mathrm{Am}\right)$ & $\begin{array}{l}\text { Gamma scan } \\
\text { (Cs removed) }\end{array}$ & $9.16 \mathrm{E}+00$ & $2.19 \mathrm{E}+00$ & $2.50 \mathrm{E}+05$ \\
\hline Americium-242m $\left({ }^{242 m} \mathrm{Am}\right)$ & $\mathrm{Am} / \mathrm{Cm}$ & $<6.58 \mathrm{E}-02$ & NA & $4.50 \mathrm{E}+05$ \\
\hline Americium-243 $\left({ }^{243} \mathrm{Am}\right)$ & $\mathrm{Am} / \mathrm{Cm}$ & $<9.32 \mathrm{E}-01$ & NA & $2.50 \mathrm{E}+05$ \\
\hline Curium-242 $\left({ }^{242} \mathrm{Cm}\right)$ & $\mathrm{Am} / \mathrm{Cm}$ & $<5.45 \mathrm{E}-02$ & NA & $1.13 E+04$ \\
\hline Curium-244 ( $\left.{ }^{244} \mathrm{Cm}\right)$ & $\mathrm{Am} / \mathrm{Cm}$ & $1.98 \mathrm{E}+01$ & 8.75E-01 & $2.50 \mathrm{E}+05$ \\
\hline Curium-245 $\left({ }^{245} \mathrm{Cm}\right)$ & $\mathrm{Am} / \mathrm{Cm}$ & $<2.47 \mathrm{E}+00$ & NA & $2.25 E+05$ \\
\hline
\end{tabular}

Tables 3-5 and 3-6 list the chemical contaminants that impact vault flammability. These chemicals must be monitored to ensure flammable gases do not contribute more than $10 \%$ of the Composite Lower Flammability Limit (CLFL). ${ }^{1}$

Table 3-5. Results for the 2nd Quarter 2013 Tank 50 Slurry Samples for Acceptance Criteria Limits for Chemical Contaminants Impacting Vault Flammability, Listed in Table 3 of the Saltstone WAC, Revision 11

\begin{tabular}{|l|c|c|c|c|}
\hline Chemical Name & Method & $\frac{\text { Average Concentration }}{\mathbf{( m g / L )}}$ & Std. Dev. & WAC Limit \\
\hline Isopar L & SVOA & $<2.67 \mathrm{E}+01 \mathrm{ppm}^{\mathrm{a}}$ & NA & $\mathbf{1 . 1 0 E}+\mathbf{0 1} \mathbf{~ p p m}$ \\
\hline $\begin{array}{l}\text { Tetraphenylborate } \\
\text { (TPB anion) }\end{array}$ & HPLC & $<5.00 \mathrm{E}+00$ & NA & $\mathbf{5 . 0 0 E + 0 0 ~} \mathbf{~ m g / L}$ \\
\hline Ammonium $\left(\mathrm{NH}_{4}{ }^{+}\right)$ & IC & $<1.00 \mathrm{E}+02$ & NA & $\mathbf{2 . 1 2 E + 0 2 ~} \mathbf{~ m g / L}$ \\
\hline
\end{tabular}

a. Result is calculated from the reported concentration of $<33 \mathrm{mg} / \mathrm{L}$ and the density of the slurry sample.

Table 3-6. Results for the 2nd Quarter 2013 Tank 50 Slurry Samples for Concentrations of "Other Organics” Impacting Vault Flammability, Listed in Table 4 of the Saltstone WAC, Revision 11

\begin{tabular}{|c|c|c|c|c|}
\hline Chemical Name & Method & $\frac{\text { Average Concentration }}{\underline{(\mathrm{mg} / \mathrm{L})}}$ & $\underline{\text { Std. Dev. }}$ & $\begin{array}{c}\frac{\text { WAC }}{\text { Concentrations }} \\
(\mathrm{mg} / \mathrm{L})\end{array}$ \\
\hline n-Butanol & VOA & $<5.00 \mathrm{E}-01$ & NA & 0.75 \\
\hline Tributylphosphate & SVOA & $<7.50 \mathrm{E}-01$ & NA & 1.0 \\
\hline i-Propanol & VOA & $<2.50 \mathrm{E}-01$ & NA & 0.25 \\
\hline Methanol & $\mathrm{a}$ & NA & NA & 0.25 \\
\hline Norpar 13 & SVOA & $<7.50 \mathrm{E}-01$ & NA & 0.1 \\
\hline
\end{tabular}

a. Currently, a routine method for detecting this species does not exist in SRNL. 
Isopar L and Norpar 13 are the only species considered in Tables 3-5 or 3-6 with reported values above the WAC limit. Although the reported detection limit for Isopar $\mathrm{L}$ is greater than the WAC limit for vault flammability, it is below the WAC limits for accident analysis as shown in Table 3-1. It should be noted that the detection limit for Isopar L was expected based on current SRNL capabilities. ${ }^{4}$ The reported detection limit for Norpar is above the WAC limit for both accident analysis (Table 3-2) and vault flammability (Table 3-6), but it is the lowest achievable MRL for this analyte. ${ }^{4}$ As previously discussed, the insolubility of Isopar L and Norpar 13 makes sub-sampling difficult, therefore the reported results are not necessarily representative of the concentration of these analytes in the Tank 50 sample received by SRNL.

Table 3-7 provides results for the processing criteria for transfers into the Saltstone Facility. All of the results contained in Table 3-7 fall within the general processing criteria. The $\mathrm{pH}$ was calculated using the free base concentration $\left(\mathrm{OH}^{-}\right)$. The low insoluble solids content makes subsampling difficult.

Table 3-7. Results for the 2nd Quarter 2013 Tank 50 Slurry Samples for Saltstone Processing Criteria WAC Limits, Listed in Table 5 of the Saltstone WAC, Revision 11

\begin{tabular}{|l|c|c|c|}
\hline Processing Criterion & Method & Value & Std. Dev. \\
\hline $\mathbf{p H}>\mathbf{1 0}$ & Calculated & $>13$ & NA \\
\hline $\mathbf{2 . 5} \mathbf{M}<\left[\mathbf{N a}^{+}\right]<\mathbf{7 . 0} \mathbf{M}$ & ICP-ES & $5.27 \mathrm{M}$ & 0.0203 \\
\hline Total Insoluble Solids $<\mathbf{1 5}$ wt.\% & Calculated & 0.165 wt.\% & 0.500 \\
\hline
\end{tabular}

Table 3-8 provides constituents listed in the Technical Task Request but not contained in the WAC.

Table 3-8. Requests for Constituents for TCLP/UHC Support as well as from the TTR for the 2nd Quarter 2013 Tank 50 Slurry Samples; Results Not Contained in Previous Tables

\begin{tabular}{|l|c|c|c|}
\hline Constituent & Method & $\begin{array}{c}\text { Average Value } \\
\text { (mg/L, unless stated otherwise) }\end{array}$ & Std. Dev. \\
\hline Antimony (Sb) & ICP-ES & $<2.99 \mathrm{E}+01$ & NA \\
\hline Beryllium (Be) & ICP-ES & $<1.04 \mathrm{E}-01$ & NA \\
\hline Cyanide (CN) & a & NA & NA \\
\hline Thallium (Tl) & ICP-MS & $<1.00 \mathrm{E}-01^{\mathrm{b}}$ & NA \\
\hline Density (slurry) & Measured $\left(22.5^{\circ} \mathrm{C}\right)$ & $1.2354 \mathrm{~g} / \mathrm{mL}$ & 0.0016 \\
\hline Total Beta & LSC & $1.14 \mathrm{E}+06 \mathrm{pCi} / \mathrm{mL}$ & $2.60 \mathrm{E}+03$ \\
\hline Total Solids & Measured & $28.61 \mathrm{wt} . \%$ & 0.221 \\
\hline
\end{tabular}

a. Currently, a routine method for detecting this species does not exist in SRNL.

b. Blank value was of comparable magnitude indicating that there may be little to no $\mathrm{Tl}$ in the sample.

The results from Table 3-8 are used to support TCLP/UHC testing by a certified laboratory. ${ }^{9}$ The density of the slurry was measured at $22.5{ }^{\circ} \mathrm{C}$. Natural $\mathrm{Tl}$ is composed of two isotopes, ${ }^{203} \mathrm{Tl}$ and ${ }^{205} \mathrm{Tl}$ with 
fractional abundances of 0.295 and 0.705 , respectively. The concentration of each isotope was divided by its fractional abundance, and the reported concentration of $\mathrm{Tl}$ is that determined from averaging the six values determined from the three replicates for each isotope.

What was unusual was that for these Tl masses, as well as those for Pb (206 - 208), the blank showed a signal of the same magnitude. The samples were analyzed a second time, but the same result was found. The digestion acids, both nitric acid and hydrochloric acid, used to perform the aqua regia digestions of the replicates were examined. The nitric acid gave no measurable signal for masses 203, $205-208$. The hydrochloric acid $(\mathrm{HCl})$ did give measurable signal at these masses; see Table 3-9. The $\mathrm{HCl}$ would be expected to contribute about $1 / 5^{\text {th }}$ of the signal measured for the blank at each mass due to the use of 9 $\mathrm{mL}$ of $\mathrm{HCl}$ diluted to a $50 \mathrm{~mL}$ final volume. For masses 203 and 205, the observed blank signal could be due to $\mathrm{Tl}$ in the $\mathrm{HCl}$, though it is a bit lower than anticipated. However, for masses $206-208$, the blank gave roughly $5 \mathrm{x}$ the signal expected if the only contribution to these masses was coming from trace $\mathrm{Pb}$ in the HCl. It should be noted that the sample is around 300 parts per trillion at the instrument. The concentrated nature of these samples, which are diluted to 1:4, versus a more typical 1:100 or even 1:400 dilution, is allowing these small values to be above the detection limit of the instrument. The entire digestion was repeated on three replicates of Tank 50 material and a blank a second time, but collected essentially the same results. In light of this, the values for both $\mathrm{Pb}$ (Table 3-1) and $\mathrm{Tl}$ are given as detection limit values since there is likely little or no $\mathrm{Pb}$ or $\mathrm{Tl}$ in these samples.

Table 3-9. Signal Observed For Masses 203 and 205 - 208 in Digestion Acid and the Tank 50 Sample Blank Showing the Contribution to the Sample Signal Expected from the Digestion Acid

\begin{tabular}{|c|c|c|c|}
\hline$\underline{\text { Mass }}$ & $\frac{\text { Concentrated HCI }}{\boldsymbol{\mu g} / \mathbf{g}}$ & $\frac{\text { Sample Blank }}{\boldsymbol{\mu g} / \mathbf{g}}$ & $\frac{\frac{\text { Acid Contribution }}{\text { Expected in Blank }}}{\boldsymbol{\mu g} / \mathbf{g}}$ \\
\hline 203 & $2.22 \mathrm{E}-01$ & $2.60 \mathrm{E}-02$ & $4.00 \mathrm{E}-02$ \\
\hline 205 & $6.08 \mathrm{E}-01$ & $6.50 \mathrm{E}-02$ & $10.9 \mathrm{E}-02$ \\
\hline 206 & $3.32 \mathrm{E}-01$ & $25.5 \mathrm{E}-02$ & $5.98 \mathrm{E}-02$ \\
\hline 207 & $3.12 \mathrm{E}-01$ & $24.0 \mathrm{E}-02$ & $5.62 \mathrm{E}-02$ \\
\hline 208 & $6.01 \mathrm{E}-01$ & $59.0 \mathrm{E}-02$ & $10.8 \mathrm{E}-02$ \\
\hline
\end{tabular}

The tank corrosion species listed in Table 3-10 were requested by SFE. ${ }^{10}$ Specific gravity was calculated by dividing the measured density of the slurry (given in Table $3-8$ at $22.5{ }^{\circ} \mathrm{C}$ ) by the density of water at the same temperature. ${ }^{11}$

Table 3-10. Requests from the SFE for Corrosion Species from the 2nd Quarter 2013 Tank 50 Slurry Samples (Results Not Contained in Previous Tables)

\begin{tabular}{|l|c|c|c|}
\hline Constituent & Method & Average Value & Std. Dev. \\
\hline Specific Gravity & a & 1.2383 & 0.0016 \\
\hline Ba-137m & b & $1.01 \mathrm{E}+06 \mathrm{pCi} / \mathrm{mL}$ & $1.13 \mathrm{E}+04$ \\
\hline Total Gamma & c & $1.01 \mathrm{E}+06 \mathrm{pCi} / \mathrm{mL}$ & $6.51 \mathrm{E}+03$ \\
\hline
\end{tabular}

a. Calculated from the measured density of slurry and density of water at $22.5^{\circ} \mathrm{C}^{11}$.

b. Calculated from the measured concentration of Cs-137.

c. Calculated from the sum of measured gamma emitters. 
The radionuclide ${ }^{137 \mathrm{~m}} \mathrm{Ba}$ is the radioactive daughter of $94.6 \%$ of the beta decay of ${ }^{137} \mathrm{Cs} .5 .3 \%$ of the ${ }^{137} \mathrm{Cs}$ decays to stable ${ }^{137} \mathrm{Ba}$. The half-life of the parent radionuclide, ${ }^{137} \mathrm{Cs}$, is five times longer than its daughter, ${ }^{137 \mathrm{~m}} \mathrm{Ba}$, therefore the two radionuclides are in secular equilibrium. Radionuclides in secular equilibrium have the same activity associated with their decay. Thus, the activity of ${ }^{137 \mathrm{~m}} \mathrm{Ba}$ is $94.6 \%$ of the activity of the ${ }^{137} \mathrm{Cs}$ or $1.01 \mathrm{E}+06 \mathrm{pCi} / \mathrm{mL}$. The activities calculated for total gamma and ${ }^{137 \mathrm{~m}} \mathrm{Ba}$ are expected to be close for this sample because the total gamma activity is dominated by ${ }^{137 \mathrm{~m}} \mathrm{Ba}$, the radioactive daughter of ${ }^{137} \mathrm{Cs}$. The total gamma activity was calculated by summing the measured gamma activity of the major gamma emitters: ${ }^{60} \mathrm{Co},{ }^{125} \mathrm{Sb},{ }^{126} \mathrm{Sb},{ }^{126} \mathrm{Sn},{ }^{137} \mathrm{Cs}$ (via ${ }^{137 \mathrm{~m}} \mathrm{Ba}$ ), ${ }^{154} \mathrm{Eu}$, and ${ }^{241} \mathrm{Am}$.

Table 3-11 provides results for additional radionuclides not listed in the WAC but which now require quantification in order to support inventory-reporting requirements.

Table 3-11. Additional Radionuclides Requested for Inventory Reporting Requirements

\begin{tabular}{|c|c|c|c|}
\hline$\underline{\text { Radionuclide }}$ & Method & $\frac{\text { Average Concentration }}{(\mathrm{pCi} / \mathrm{mL})}$ & $\underline{\text { Std. }}$ Dev. \\
\hline Niobium-93m $\left({ }^{93 \mathrm{~m}} \mathrm{Nb}\right)$ & ICP-MS & $<4.24 \mathrm{E}+01$ & NA \\
\hline Silver-108m $\left({ }^{108 m} \mathrm{Ag}\right)$ & $\begin{array}{c}\text { Gamma scan } \\
\text { (Cs removed) }\end{array}$ & $<4.21 \mathrm{E}-01$ & NA \\
\hline Barium-133 $\left({ }^{133} \mathrm{Ba}\right)$ & $\begin{array}{l}\text { Gamma scan } \\
\text { (Cs removed) }\end{array}$ & $<6.44 \mathrm{E}-01$ & NA \\
\hline Bismuth-207 $\left({ }^{207} \mathrm{Bi}\right)$ & $\begin{array}{l}\text { Gamma scan } \\
\text { (Cs removed) }\end{array}$ & $<4.12 \mathrm{E}-01$ & NA \\
\hline Thorium-228 $\left({ }^{228} \mathrm{Th}\right)$ & $\begin{array}{r}\text { Gamma scan } \\
\text { (Cs removed) }\end{array}$ & $<8.47 \mathrm{E}+00$ & NA \\
\hline Curium-247 ( $\left({ }^{247} \mathrm{Cm}\right)$ & $\mathrm{Am} / \mathrm{Cm}$ & $<5.18 \mathrm{E}+00$ & NA \\
\hline Californium-249 $\left({ }^{249} \mathrm{Cf}\right)$ & $\mathrm{Am} / \mathrm{Cm}$ & $<5.41 \mathrm{E}+00$ & NA \\
\hline Californium-251 ( $\left.{ }^{251} \mathrm{Cf}\right)$ & $\mathrm{Am} / \mathrm{Cm}$ & $<4.00 \mathrm{E}+00$ & NA \\
\hline
\end{tabular}

\subsection{Conclusions}

The following conclusions are drawn from the analytical results provided in this report:

- $\quad$ SRR WAC targets or limits were met for all analyzed chemical and radioactive contaminates unless noted in this section.

- $\quad{ }^{59} \mathrm{Ni},{ }^{94} \mathrm{Nb},{ }^{247} \mathrm{Cm},{ }^{249} \mathrm{Cf}$, and ${ }^{251} \mathrm{Cf}$ are above the requested SRR target concentrations ${ }^{2}$. However, they are below the detection limits established by SRNL ${ }^{3}$.

- Norpar 13 and Isopar L have higher detection limits ${ }^{4}$ compared with the Saltstone WAC ${ }^{1}$. The data provided in this report is based upon the concentrations in the sub-sample, and due to the limited solubility in aqueous solution, may not represent the concentrations of the analytes in Tank 50.

- The low insoluble solids content increases the measurement uncertainty for insoluble species. 
SRNL-STI-2013-00390

Revision 0

\subsection{References}

1. Chiu, C. K., Waste Acceptance Criteria for Aqueous Waste Sent to the Z-Area Saltstone Production Facility; X-SD-Z-00001, Rev. 11; Savannah River Site: Aiken, SC 29808, 2012.

2. D. B. Dixon, Minimum Detection Limits for Saltstone Quarterly WAC Analyses; SRR-WSE-201300005, Rev. 1, January 2013.

3. DiPrete, C. C., Overview of Capability to Measure Radionuclides of Interest for Saltstone; SRNLL4000-2009-00028; Savannah River National Laboratory: Aiken, SC 29808, 2009.

4. Crump, S. L., Determination of Method Reporting Limits for Select Analytes by GC/MS; SRNL-TR2010-00206, Rev. 0; Savannah River National Laboratory: Aiken, SC 29808, 2010.

5. Isom, S. T., Routine Saltstone Support - FY2013; HLW-SSF-TTR-2012-0021; Savannah River Site: Aiken, SC 29808, 2012.

6. Reigel, M. M., Task Technical and Quality Assurance Plan for SRNL Support of Tank 50H Waste Acceptance Criteria (WAC) Analyses - FY2013; SRNL-RP-2012-00814, Rev. 0; Savannah River National Laboratory: Aiken, SC 29808, 2012.

7. Coleman, C. J., “Aqua Regia Dissolution of Sludge for Elemental Analysis"; Manual L16.1, Procedure ADS-2226, Rev. 9; Savannah River National Laboratory, Aiken, SC 29808, 2009.

8. Touabet, A., Abdeddaim, K., Guermouche, Moulay-Hassane, Study of the Reaction of Ethyl- and Methylmercury Chloride with Diphenylmercury by GC-MS; J. High Res. Chrom. \& Chrom. Comm., 1981, 4, $525-526$.

9. Reigel, M. M. Task Technical and Quality Assurance Plan for SRNL Support of TCLP Preparation and Analysis for Saltstone - FY2013; SRNL-RP-2012-00859, Rev. 0; Savannah River National laboratory: Aiken, SC 29808; 2013.

10. Hevel, S. D., Email TTR Revision Request, SRNL Laboratory Notebook, WSRC-NB-2007-00189, pg. 30, December 20, 2007.

11. Handbook of Chemistry and Physics, $90^{\text {th }}$ ed.; Edited by Lide, D. R., CRC Press: Boca Raton, FL, 2009. 
SRNL-STI-2013-00390

Revision 0

This page intentionally left blank 


\section{Distribution}

\begin{tabular}{|c|c|c|c|}
\hline Name: & Location: & Name: & Location: \\
\hline P. M. Almond & 773-43A & V. Jain & $704-Z$ \\
\hline C. J. Bannochie & $773-42 \mathrm{~A}$ & C. A. Langton & 773-43A \\
\hline M. J. Barnes & 773-A & J. N. Leita & $704-30 S$ \\
\hline L. W. Brown & 773-A & K. R. Liner & $704-S$ \\
\hline T. B. Brown & 773-A & M. J. Mahoney & 766-H \\
\hline P. L. Bovan & $704-27 S$ & S. L. Marra & 773-A \\
\hline N. F. Chapman & 766-H & D. J. Martin & $241-246 \mathrm{H}$ \\
\hline C. K. Chiu & $704-27 S$ & P. W. Norris & $704-Z$ \\
\hline D. R. Click & 999-W & E. Patten & $704-Z$ \\
\hline L. H. Connelly & 773-A & F. M. Pennebaker & $773-42 \mathrm{~A}$ \\
\hline J. S. Contardi & 766-H & J. W. Ray & $704-S$ \\
\hline A. D. Cozzi & 999-W & M. M. Reigel & 999-W \\
\hline C. C. DiPrete & 773-A & L. B. Romanowski & 766-H \\
\hline K. D. Dixon & $704-14 Z$ & E. R. Seldon & $704-Z$ \\
\hline C. E. Duffey & 704-61H & A. R. Shafer & $704-27 S$ \\
\hline A. D. England & $704-14 Z$ & D. C. Sherburne & 704-S \\
\hline S. D. Fink & 773-A & F. M. Smith & $705-1 C$ \\
\hline E. J. Freed & $704-56 \mathrm{H}$ & A. V. Staub & $704-Z$ \\
\hline J. C. Griffin & 773-A & K. H. Subramanian & $249-8 \mathrm{H}$ \\
\hline E. W. Harrison & 704-60H & J. R. Vitali & 704-71F \\
\hline P. J. Hill & 766-H & T. L. White & 773-A \\
\hline E. N. Hoffman & 999-W & A. W. Wiggins & 704-61H \\
\hline P. R. Jackson & $703-46 A$ & R. H. Young & 773-A \\
\hline
\end{tabular}

